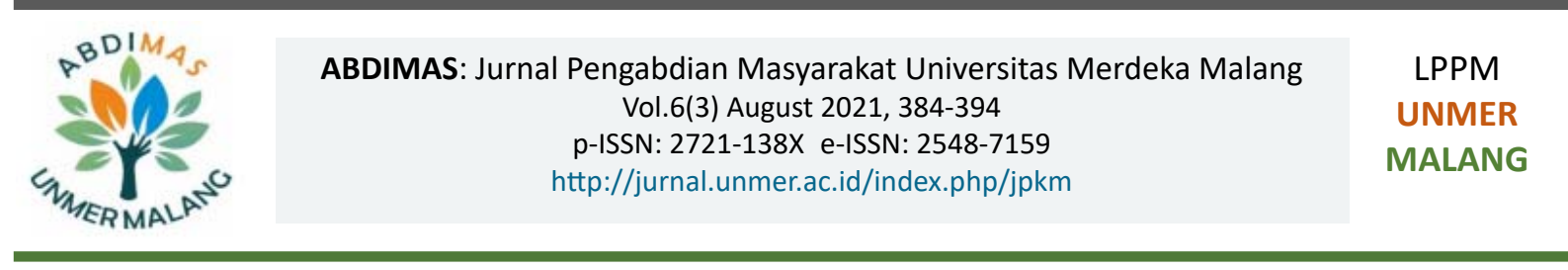

\title{
Implementasi Digital Marketing pada Pengrajin Tas Anyam Desa Pesidi Kecamatan Grabag, Kabupaten Magelang
}

\author{
Nur Hidayah1', Irfan Maulana1, Seto Priyambodo Suryawan', Siti Nur Halimatus Sa'diah', Sita \\ Indriyani², Latifur Rizka² \\ 'Departemen Manajemen, ²Departemen Akuntansi, Fakultas Ekonomi dan Bisnis, Universitas Muhammadiyah Magelang, \\ Jl. Tidar No. 21 Magelang, 56125, Indonesia
}

ARTICLE INFO
Received: 2021-01-24
Revised: 2021-03-06
Accepted: 2020-06-14
Keywords:
Craftsman, Digital
marketing, Woven bag

\section{ABSTRACT}

People in Pesidi village have an additional livelihood as woven bag craftsman. Many housewives become craftsman because the production time is flexible and can be done at home. However, the problems faced by woven bag craftsman include the lack of product innovation, conventional sales systems, low selling prices resulting in low income, craftsman not having knowledge of digital marketing, and inventory buildup due to lack of sales. The purpose of this community service is to increase digital marketing knowledge and reduce the problems of woven bag craftsman. The methods used are socialization to local government and craftsman, training (lectures, simulations, and discussions), and assistance in making digital marketing. The results of the service are in the form of marketing innovation through digital marketing, an increase in income of $7 \%$, an increase in the understanding of woven bag craftsman about digital marketing, and product sales with an online system via email, Facebook, Instagram, and market places available on digital platforms.

(C)2021 Published by University of Merdeka Malang. This is an open access article distributed under the CC BY-SA 4.0 license (https://creativecommons.org/licenses/by-sa/4.0/)

\footnotetext{
How to cite: Hidayah, N., Maulana, I., Suryawan, S. P., Sa'diah, S. N. H., Indriyani, S., \& Rizka, L. (2021). Implementasi Digital Marketing pada Pengrajin Tas Anyam Desa Pesidi Kecamatan Grabag, Kabupaten Magelang. Abdimas: Jurnal Pengabdian Masyarakat Universitas Merdeka Malang, 6(3), xxx-xxx. https://doi.org/10.26905/abdimas.v6i3.5347
}

\section{PENDAHULUAN}

Pandemi COVID-19 memberikan dampak yang cukup besar di berbagai sektor industri terutama pada usaha mikro kecil menengah (UMKM). Hal ini disebabkan oleh berubahnya perilaku konsumen yang mengurangi kontak dengan orang lain dan beralih pada penggunaan alat pembayaran non tunai seperti e-money, prepaid, kartu debit/kredit, ponsel, dan sebagainya. Adanya perubahan perilaku konsumen ini para pelaku usaha mikro kecil menengah harus beradaptasi menggunakan teknologi agar dapat mempertahankan usaha. Akan tetapi, masih banyak pelaku usaha mikro kecil dan menengah yang memiliki pemahaman dan literasi terkait strategi branding dan marketing. Menurut Purwana et al. (2017) 
Digital marketing adalah kegiatan promosi dan pencarian pasar melalui media digital secara online dengan memanfaatkan berbagai sarana misalnya jejaring sosial. Saat ini penggunaan digital marketing sangat membantu dalam memasarkan produk atau jasa dengan cara yang cepat, jangkauan luas, dan biaya yang murah (Purwaningsih, Suhaeri, \& Ariyanti, 2020; Setiyaningsih \& Fahmi, 2020; Chaffey \& Ellis-Chadwick, 2019). Ada beberapa perbedaan antara online marketing dan marketing tradisional yang disajikan dalam Tabel 1.

Tabel 1. Perbedaan online marketing dan marketing tradisional

\begin{tabular}{|c|c|c|}
\hline & Online Marketing & Marketing Tradisional \\
\hline Modal & $\begin{array}{l}\text { - Lokasi usaha-usaha online: website, market- } \\
\text { place, social media } \\
\text { - Renovasi: tampilan website, marketplace, social } \\
\text { media } \\
\text { - Kelengkapan: klik menu } \\
\text { - Ketersediaan produk: upload gambar produk } \\
\text { - Karyawan: tidak ada / Sedikit } \\
\text { - Free promotion }\end{array}$ & $\begin{array}{l}\text { - Lokasi: biaya sewa yang mahal pada lokasi } \\
\text { yang strategis } \\
\text { - Renovasi: membutuhkan banyak biaya } \\
\text { perbaikan } \\
\text { - Kelengkapan: kebutuhan perlengkapan } \\
\text { yang tidak sedikit } \\
\text { - Ketersediaan Produk: persediaan produk } \\
\text { banyak karena untuk display produk } \\
\text { - Karyawan: lebih banyak karyawan } \\
\text { - Biaya promosi yang tidak sedikit }\end{array}$ \\
\hline Waktu & $\begin{array}{l}\text { - Tidak perlu menjaga website karena tidak ber- } \\
\text { tatap muka dengan customer secara langsung. } \\
\text { - Komunikasi dengan konsumen bisa melalui mes- } \\
\text { sanger, email, atau telepon dengan menggunakan } \\
\text { smartphone dimanapun dan kapanpun. }\end{array}$ & $\begin{array}{l}\text { Waktu yang kurang fleksibel. Seseorang } \\
\text { yang bekerja sambil berbisnis akan sulit un- } \\
\text { tuk membagi waktu, karena harus menjaga } \\
\text { toko. }\end{array}$ \\
\hline Kemampuan & $\begin{array}{l}\text { Banyak perusahaan jasa yang menawarkan pem- } \\
\text { buatan toko online dengan system easy to use. } \\
\text { Keunggulan Digital Marketing adalah jangkauan } \\
\text { pemasaran lebih luas dan waktu yang tidak ter- } \\
\text { batas. }\end{array}$ & $\begin{array}{l}\text { Marketing tradisional memiliki beberapa } \\
\text { hambatan: (1) Pemula yang kurang percaya } \\
\text { diri karena belum memiliki pengalaman dan } \\
\text { kemampuan bisnis yang masih belum me- } \\
\text { madai; (2) Belum menguasai pemasaran; (3) } \\
\text { Belum mempunyai kemampuan dalam men- } \\
\text { gatur karyawan; (4) Belum memiliki ide. }\end{array}$ \\
\hline
\end{tabular}

Sumber: Awali (2020)

Aplikasi e-marketing cocok untuk ekspansi pasar karena dapat menjangkau konsumen lebih luas lagi. Dengan e-marketing, penyebaran informasi pemasaran menjadi lebih maksimal dalam memasarkan barang atau jasa, serta memudahkan konsumen untuk mendapat informasi terkait produk yang ditawarkan (Supriyani \& Untari, 2021; Awali, 2020). Menurut We are Social (2020), platform media sosial yang paling banyak digunakan di Indonesia per Januari 2017 yaitu, pertama Youtube sebanyak 49\%, Facebook sebanyak 48\%, Instagram sebanyak 39\%, Twitter sebanyak 38\%, Whatsapp sebanyak 38\%, dan Google sebanyak 36\%. Sisanya adalah FB Messenger, Line, Linkedin, BBM, Pinterest, dan Wechat. 
ABDIMAS: Jurnal Pengabdian Masyarakat Universitas Merdeka Malang Volume 6, No 3, August 2021: 384-394

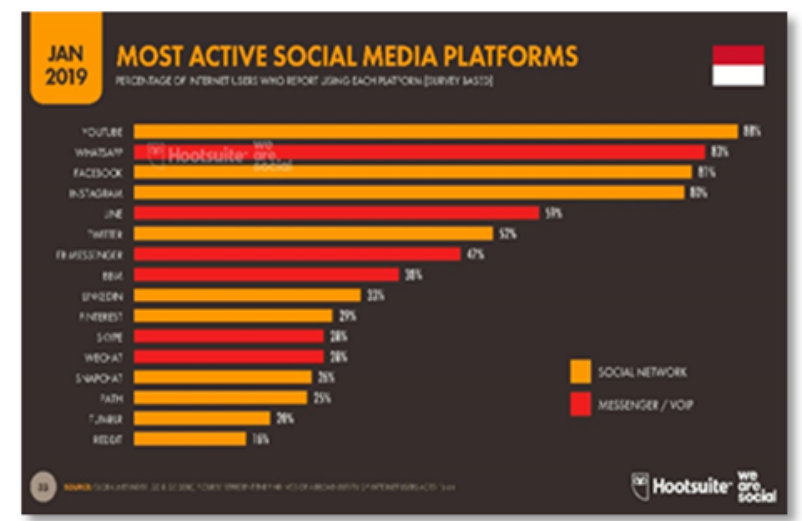

Gambar 1. Platform media sosial yang paling sering digunakan di Indonesia (We are Social, 2020)

Berdasarkan Gambar 1, pemanfaatan digital marketing masih belum maksimal jika dilihat dari pertumbuhan jumlah pengguna internet yang sangat tinggi. Berdasarkan riset McKinsey, baru sekitar 30\% usaha di Indonesia yang menggunakan digital marketing dalam melakukan perkembangan usahanya (Supriadi, 2016). Dengan penggunaan digital marketing dapat memotong mata rantai penjualan yang panjang dan target pemasarannya menjadi lebih luas hingga jangkauannya ke seluruh daerah di Indonesia (Rozinah \& Meiriki, 2020; Setiyaningsih \& Fahmi, 2020). Dari hal tersebut, dapat disimpulkan bahwa digital marketing di Indonesia memiliki potensi yang sangat besar.

Desa Pesidi merupakan salah satu desa yang terletak di Kabupaten Magelang tepatnya berada di Kecamatan Grabag, sekitar 18 KM dari Kota Magelang. Di desa ini terdapat sebuah usaha kerajinan tas anyam. Sebelumnya usaha kerajinan tas anyam ini belum memiliki nama atau brand, tetapi setelah kegiatan pengabdian berlangsung, usaha kerajinan tas anyam diberi label nama Webbing.co.

Penduduk Desa Pesidi pada tahun 2020 adalah sebanyak 187 KK dan rata-rata bekerja sebagai buruh anyam di Webbing.co. Menjadi buruh pengrajin tas anyam di Webbing.co merupakan sumber alternatif tambahan pendapatan bagi penduduk Desa Pesidi. Tambahan pendapatan ini digunakan untuk memenuhi kebutuhan rumah tangga. Pendapatan dari tas anyam digunakan ibu rumah tangga untuk memenuhi kebutuhan keluarga yang tidak tercukupi dari penghasilan utama yang berasal dari sektor pertanian dan perdagangan. Pembuatan tas anyam juga dapat menggunakan bahan-bahan limbah (seperti tali pengepak) sehingga dapat mengurangi limbah dan menjaga ekosistem lingkungan (Dewi et al., 2018). Akan tetapi, ada beberapa kendala yang dihadapi oleh Webbing.co sebagai perusahaan yang memproduksi tas anyam tersebut, seperti: (1) Tidak ada inovasi produk; (2) Sistem penjualan konvensional (tidak memanfaatkan teknologi) hanya mengandalkan pembeli dari Kota Magelang untuk membeli produk kerajinan yang dihasilkan; (3) Harga yang rendah sehingga menghasilkan pendapatan yang rendah berkisar antara Rp2.000.000-Rp5.000.000/bulan tergantung pesanan. Akan tetapi semenjak pandemi, menjadi Rp900.000 (kurang dari Rp1.000.000); (4) Pengrajin tidak memiliki pengetahuan terkait digital marketing; (5) Penumpukan produk di gudang karena tidak terjual. 

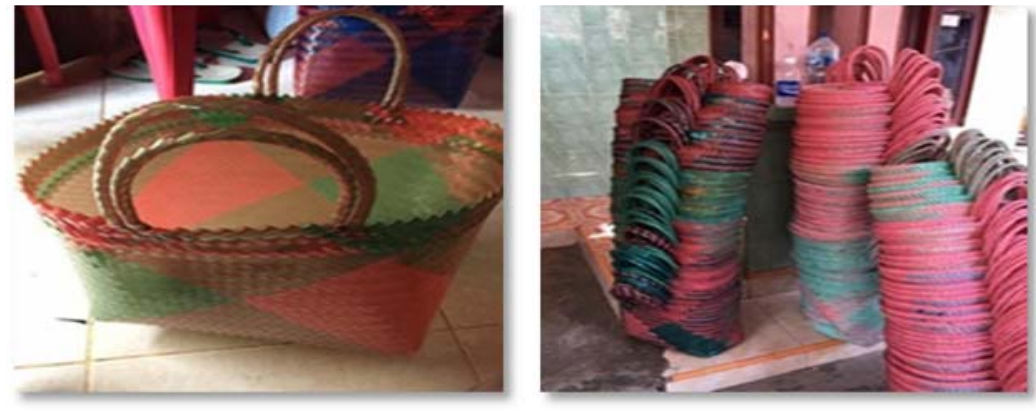

Gambar 2. Tas anyam

Gambar 3. Penumpukan produk di gudang

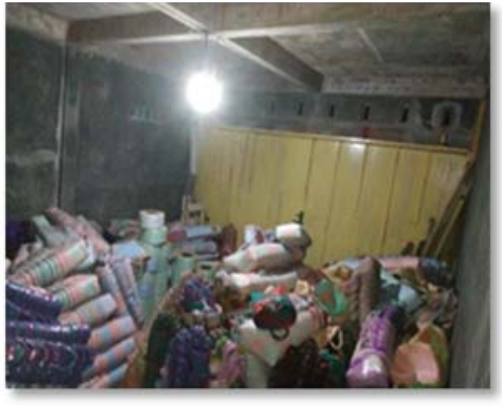

Kendala-kendala tersebut mengakibatkan lemahnya jaringan usaha, keterbatasan kemampuan pemasaran terutama kaitannya dengan literasi digital marketing, skala ekonomi yang kecil sehingga berakibat pada sukarnya penekanan biaya, profit yang sangat kecil, dan produk yang tidak memiliki keunggulan kompetitif. Hal tersebut menyebabkan bisnis tas anyam Webbing.co berjalan stagnan tanpa ada peningkatan bisnis. Berdasarkan kondisi tersebut, maka perlu diberikan pelatihan dan pendampingan kepada pelaku usaha tas anyam agar dapat memanfaatkan digital marketing yang berguna untuk penjualan produk, sehingga dapat memperoleh penghasilan yang lebih layak. Jejaring sosial atau media sosial memiliki potensi untuk membantu pelaku UKM untuk dapat memasarkan produk dan jasanya (Budiyanto et al., 2020; Stelzner, 2015).

Menurut Bajpai et al. (2012) media sosial merupakan bentuk dari hubungan masyarakat yang paling transparan, menarik dan interaktif pada saat ini karena media sosial lebih cepat menarik perhatian. Hal ini dapat dijadikan solusi dalam membangun kesadaran merk pada konsumen melalui media social. Tidak hanya itu, sifat dari media sosial yang terbuka dapat dimanfaatkan oleh pelaku usaha khususnya usaha kecil dan menengah (UKM) untuk memasarkan produk atau jasanya. Pelaku usaha dapat mengatur social media mereka dengan display foto dan detail produk melalui media sosial seperti Facebook, Twitter, dan Instagram. Cara seperti ini dapat dikatakan cara yang paling efektif dan dapat menekan biaya. Oleh karena itu, beberapa alternatif penanganan masalah yang dilakukan adalah sebagai berikut: (1) Jalur marketing (Marketing Octopus) di antaranya media Facebook, Instagram, Whatsapp, pamflet, marketplace, jaringan, link bisnis, web; (2) Proactive Networking (Jaringan) di antaranya komunitas, event, sosialita, kongkow; (3) Differeniator (mengapa orang lain harus membeli produk anda?) di antaranya unik, beda, pelayanan, komunikasi, dan pembelian yang rumit.

Tabel 2. Penyebab, dampak, dan alternatif penanganan

\begin{tabular}{|c|c|c|}
\hline Penyebab & Dampak & Alternatif Penanganan \\
\hline $\begin{array}{l}\text { - Manajemen pemasaran yang sangat } \\
\text { konvensional serta cenderung pasif } \\
\text { - Desain produk yang masih sangat } \\
\text { sederhana dan kurang inovatif } \\
\text { - Struktur organisasi sederhana de- } \\
\text { ngan pembagian kerja yang tidak } \\
\text { sesuai } \\
\text { - Kualitas manajemen dan teknologi } \\
\text { yang sangat rendah }\end{array}$ & $\begin{array}{l}\text { - Jaringan usaha yang belum luas } \\
\text { - Keterbatasan pengetahuan pe- } \\
\text { masaran } \\
\text { - Skala ekonomi yang sangat kecil } \\
\text { sehingga sukar untuk melaku- } \\
\text { kan penekanan biaya } \\
\text { - Profit sedikit } \\
\text { - UMKMtidakmemiliki keunggul- } \\
\text { an kompetitif. }\end{array}$ & $\begin{array}{l}\text { - Jalur marketing (Marketing Octopus) } \\
\text { seperti media Facebook, Instagram, } \\
\text { Whatsapp, pamflet, marketplace, jaringan, } \\
\text { link bisnis, web. } \\
\text { - Proactive Networking (Jaringan) sepert } \\
\text { komunitas, event, sosialita, kongkow. } \\
\text { - Differeniator (mengapa orang lain harus } \\
\text { membeli produk anda?) seperti unik, } \\
\text { beda, pelayanan, komunikasi, dan pem- } \\
\text { belian tidak rumit. }\end{array}$ \\
\hline
\end{tabular}


ABDIMAS: Jurnal Pengabdian Masyarakat Universitas Merdeka Malang Volume 6, No 3, August 2021: 384-394

Berdasarkan hasil pemetaan Tabel 2 yang menunjukkan bahwa pelaku usaha mengalami kesulitan dalam mengatur usahanya akibat sepinya pembeli dan kurang luasnya pengetahuan tentang digital marketing. Pemasaran merupakan hal yang sangat penting bagi suatu usaha, dengan pemasaran yang tepat, suatu usaha akan berhasil. Pemasaran membutuhkan effort yang sangat tinggi untuk dapat melewati company life cycle yaitu dari awal peluncuran produk, pertumbuhan produk, munculnya pesaing, pengembangan produk baru, ekspansi pasar, sampai dengan declined stage atau kemunduran bisnis (Tinaprilia, 2007). Program pengabdian ini bertujuan untuk mengembangkan UMKM Webbing. co yang ada dari segi pemasaran, terwujudnya partisipasi karyawan UMKM dalam optimalisasi produksi yang ada dan bertambahnya pengetahuan literasi terkait digital marketing. Diharapkan setelah dilakukan pelatihan dan pendampingan dapat membantu pihak tersebut dalam menangani permasalahan yang dihadapi dan keberlanjutan usaha sehingga membantu peningkatan ekonomi skala kecil.

\section{METODE}

Metode pelaksanaan program pengabdian masyarakat terpadu melalui sosialisasi, pelatihan, dan pendampingan terkait pemasaran. Mitra pengabdian ini adalah UMKM tas anyam yaitu Webbing.co. Lokasi pelaksanaan pengabdian di UMKM Webbing.co yang beralamat di Desa Pesidi, RT.1/RW.3, Kecamatan Grabag, Kabupaten Magelang. Berikut uraian kegiatan terkait metode pelaksanaan berdasarkan jenis dan tujuan antara lain sebagai berikut (Widhiastuti et al., 2019).

\section{Sosialisasi}

Kegiatan sosialisasi bertujuan untuk memberikan pemahaman dan perlunya kesadaran akan pentingnya pemasaran untuk berlangsungnya kegiatan usaha melalui sarana pemasaran online seperti media sosial Facebook, Instagram, Twitter dan media sosial lainnya serta menandai lokasi usaha di Google Map. Kegiatan sosisalisasi dilakukan dalam 2 kali pertemuan masing-masing selama 8 jam dengan rincian sebagai berikut: (1) Sosialisasi kepada pemerintah desa dalam rangka memberi tahu maksud dan tujuan diadakannya pelaksanaan pengabdian mengenai pengembangan model pemasaran di Desa Pesidi; (2) Sosialisasi kepada pengrajin dalam rangka memberikan gambaran mengenai pentingnya digital marketing.

\section{Pelatihan}

Kegiatan pelatihan merupakan rangkaian tahap kedua sebagai upaya tindak lanjut dari hasil kegiatan sosialisasi. Pelatihan ini bertujuan untuk memberikan pemahaman pemasaran berbasis online kepada pengrajin guna mengoptimalkan pemasaran, sehingga produk yang dihasilkan dapat diketahui oleh masyarakat luas. Kegiatan pelatihan dilakukan dalam 1 kali pertemuan selama 6 jam dengan rincian metode sebagai berikut: (1) Metode ceramah, dengan memberikan penyuluhan materi tentang digital marketing (sarana pemasaran online menggunakan media sosial seperti Facebook, Instagram dan media sosial lainnya, serta menandai lokasi usaha UMKM di Google Map); (2) Metode simulasi, dengan contoh penerapan digital marketing; (3) Metode diskusi, dengan memberikan kesempatan tanya jawab kepada 
pengrajin mengenai hal-hal yang belum atau tidak mereka pahami tentang model pemasaran yang disampaikan oleh pemateri.

\section{Pendampingan}

Kegiatan pendampingan merupakan rangkaian tahap ketiga setelah kegiatan sosialisasi dan pelatihan. Pendampingan ini ditujukan untuk membantu permasalahan-permasalahan yang muncul saat pengrajin secara mandiri menerapkan model pemasaran online. Pendampingan dilaksanakan dalam 16 kali pendampingan masing-masing selama 3 jam.

Tabel 3. Jadwal dan tahapan pelaksanaan

\begin{tabular}{|c|c|c|c|}
\hline $\begin{array}{l}\text { Hari/Tang- } \\
\text { gal }\end{array}$ & Kegiatan Dan Dokumen Pendukung & Waktu & Hasil \\
\hline $\begin{array}{l}\text { Jumat, } \\
2 / 10 / 2020\end{array}$ & $\begin{array}{l}\text { - Penerjunan kegiatan PPMT } \\
\text { - Pembukaan }\end{array}$ & $1 \times 4$ Jam & $\begin{array}{l}\text { - DPL menyerahkan mahasiswa } \\
\text { PPMT di lokasi setempat } \\
\text { - Pengenalan kegiatan PPMT ke- } \\
\text { pada masyarakat }\end{array}$ \\
\hline $\begin{array}{l}\text { Senin, } \\
5 / 10 / 2020\end{array}$ & $\begin{array}{l}\text { Sosialisasi Tahap I } \\
\text { - Penjelasan dan pemaparan materi digital } \\
\text { marketing } \\
\text { - Sesi tanya jawab antara mahasiswa dan } \\
\text { kelompok UMKM }\end{array}$ & $1 \times 5$ Jam & $\begin{array}{l}\text { Kelompok UMKM mengetahui apa } \\
\text { pentingnya digital marketing }\end{array}$ \\
\hline $\begin{array}{l}\text { Rabu, } \\
7 / 10 / 2020\end{array}$ & $\begin{array}{l}\text { Sosialisasi Tahap II } \\
\text { - Penjelasan dan pemaparan mengenani } \\
\text { pentingnya personal branding } \\
\text { - Sesi tanya jawab antara mahasiswa dan } \\
\text { kelompok UMKM }\end{array}$ & $1 \times 5$ Jam & $\begin{array}{l}\text { Kelompok UMKM mengetahui apa } \\
\text { pentingnya personal branding }\end{array}$ \\
\hline $\begin{array}{l}\text { Jumat, } \\
\text { 9/10/2020 }\end{array}$ & $\begin{array}{l}\text { Pelatihan dan pendampingan } \\
\text { - Pelatihan dan pendampingan pembuatan } \\
\text { digital marketing berupa social media dan } \\
\text { marketplace } \\
\text { - Pelatihan dan pendampingan peng- } \\
\text { gunaan social media untuk melakukan } \\
\text { pemasaran dengan digital marketing } \\
\text { kepada kelompok usaha Dusun Pesidi } 1\end{array}$ & $3 \times 5$ Jam & $\begin{array}{l}\text { - Kelompok UMKM mengetahui } \\
\text { pembuatan digital marketing } \\
\text { berupa social media dan Market- } \\
\text { place } \\
\text { - Kelompok UMKM mengetahui } \\
\text { bagaimana caranya melakukan } \\
\text { pemasaran dengan digital market- } \\
\text { ing }\end{array}$ \\
\hline $\begin{array}{l}\text { Jumat, } \\
16 / 10 / 2020\end{array}$ & $\begin{array}{l}\text { Pelatihan dan pendampingan dalam } \\
\text { melakukan personal branding terhadap } \\
\text { produk UMKM Dusun Pesidi } 1\end{array}$ & $3 \times 5$ Jam & $\begin{array}{l}\text { Melakukan personal branding terh- } \\
\text { adap produk UMKM Dusun Pesidi } 1\end{array}$ \\
\hline $\begin{array}{l}\text { Kamis, } \\
21 / 10 / 2020\end{array}$ & $\begin{array}{l}\text { Pemasangan brand atau merek pada } \\
\text { produk UMKM Dusun Pesidi } 1\end{array}$ & $3 \times 4$ Jam & $\begin{array}{l}\text { Pemberian brand atau merek pada } \\
\text { produk UMKM Dusun Pesidi } 1\end{array}$ \\
\hline $\begin{array}{l}\text { Senin, } \\
26 / 10 / 2020\end{array}$ & Penjualan melalui social media & $1 \times 7$ Jam & $\begin{array}{l}\text { Penjualan yang dilakukan melalui } \\
\text { social media Facebook menghasil- } \\
\text { kan pendapatan omset dari bebera- } \\
\text { pa pembeli }\end{array}$ \\
\hline
\end{tabular}


ABDIMAS: Jurnal Pengabdian Masyarakat Universitas Merdeka Malang Volume 6, No 3, August 2021: 384-394

\section{HASIL DAN PEMBAHASAN Hasil}

Keberhasilan program ini dapat dilihat dari peningkatan keberdayaan pengrajin tas anyam melalui peningkatan income, peningkatan indeks penggunaan digital marketing, kemauan pengrajin pada aspek partisipasi penduduk Pesidi 1 baik pria maupun wanita. Sosialisasi yang dilakukan menghasilkan beberapa penyampaian materi yang sudah disusun dan dipersiapkan agar dapat diterima pengrajin yang bersangkutan.

Pada Gambar 4, dilakukan sosialisasi kepada mitra terkait konsep dasar digital marketing yang meliputi pengertian, tujuan, konsep, jenis, manfaat dan keuntungan, strategi, metode, perbedaan, dan contoh digital marketing.

Selanjutnya adalah pelatihan. Pelatihan pertama yang dilakukan menghasilkan pembuatan social media berupa marketplace Facebook dan Shopee. Mitra diajarkan cara membuat gerai online untuk pemasaran produk tas anyam secara online. Hal ini bertujuan untuk perluasan pangsa pasar agar produk dapat lebih dikenal ke berbagai daerah karena selama ini pangsa pasar lokal saja. Selain itu, untuk meningkatkan income di masa pandemi agar tetap eksis dan tidak melakukan pengurangan pengrajin sehingga tidak meningkatkan pengangguran.
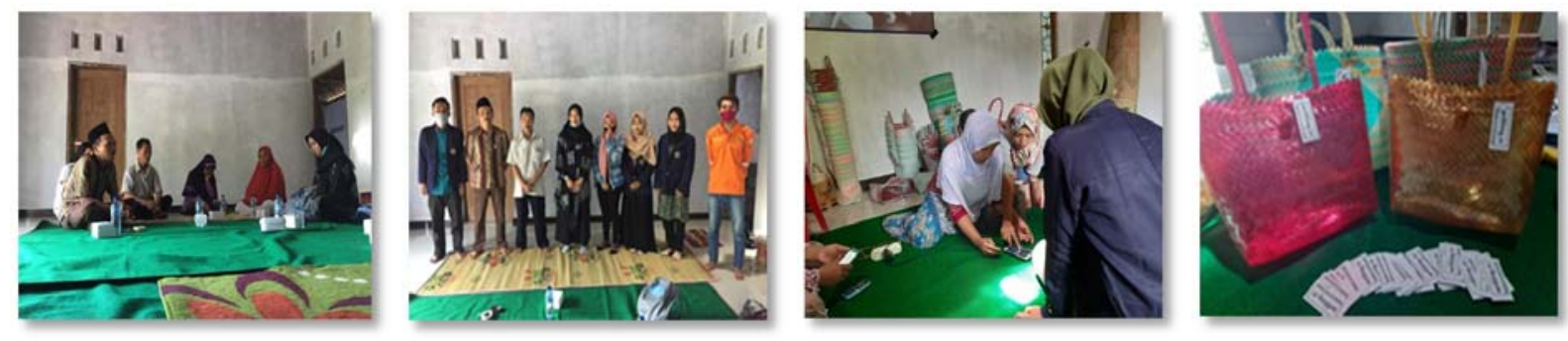

Gambar 4. Sosialisasi digital marketing

Gambar 5. Pelatihan pembuatan sosial media

Hasil dari pelatihan pembuatan sosial media adalah akun toko di marketplace facebook dan shopee yang dapat dilihar pada Gambar 6.
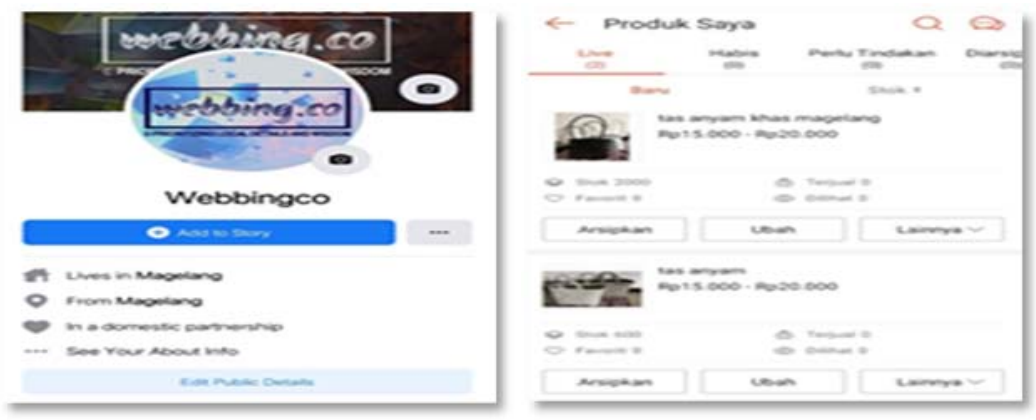

Gambar 6. Pembuatan online shop di Facebook dan Shopee

Selama ini metode penjualan diborong oleh pedagang besar dengan harga yang yang sangat murah. Untuk memotong mata rantai penjualan tersebut, maka toko online menjadi solusinya. Pengrajin 
mendapatkan untung sedikit dari penjualan kepada pedagang besar. Adapun hasil capaian progam ini antara lain: (1) Perbaikan model dan tampilan produk sehingga diperoleh kepuasan konsumen dan bisa menentukan harga selayaknya; (2) Peningkatan partisipasi dan kinerja pemasaran pada usaha yang mereka jalankan; (3) Perbaikan sistem pemasaran baik pada lingkup pada metode ataupun proses pemasaran sehingga usaha yang mereka jalankan semakin maju dalam skala nasional/internasional.

\section{Pembahasan}

Dalam rangka menumbuhkembangkan UMKM dan menciptakan peluang pasar agar jaringan usaha lebih luas dan dikenal dalam skala nasional ataupun internasional, diperlukan alternatif dan juga teknologi yang memadai, sehingga pengenalan produk lebih maksimal. Pemilihan penggunaan jaringan juga akan mempengaruhi stabilitas penggunaan sosial media. Berdasarkan analisis keterlaksanaan kegiatan selama pelatihan dan pendampingan yang telah dilakukan oleh masyarakat Pesidi 1 dapat dilihat pada Tabel 4.

Tabel 4. Keterlaksanaan kegiatan

\begin{tabular}{|c|c|c|c|c|}
\hline \multirow{2}{*}{ Pernyataan } & \multicolumn{4}{|c|}{ skor } \\
\hline & 1 & 2 & 3 & 4 \\
\hline $\begin{array}{l}\text { Kesesuaian kegiatan pengabdian dengan kebutuhan masyarakat } \\
\text { produktif }\end{array}$ & - & - & 80,0 & 20,0 \\
\hline Kerjasama pengabdi dengan masyarakat produktif & - & 35,5 & 47,0 & 17,5 \\
\hline Memunculkan aspek pemberdayaan masyarakat & - & 29,5 & 53,0 & 17,5 \\
\hline Meningkatkan motivasi masyarakat untuk berkembang & - & 18,0 & 41,0 & 41,0 \\
\hline Sikap/perilaku pengabdi di lokasi pengabdian & - & 45,0 & 45,0 & 10,0 \\
\hline $\begin{array}{l}\text { Komunikasi/koordinasi LP3M dengan penanggung jawab lokasi peng- } \\
\text { abdi }\end{array}$ & - & 45,0 & 45,0 & 10,0 \\
\hline Kesesuaian waktu pelaksanaan dengan kegiatan & 6,0 & 47,0 & 47,0 & - \\
\hline Kesesuaian keahlian pengabdi dengan kegiatan pengabdian & - & 53,0 & 47,0 & - \\
\hline $\begin{array}{l}\text { Hasil pengabdian dapat dimanfaatkan masyarakat produktif/non } \\
\text { produktif }\end{array}$ & - & 23,5 & 41,0 & 35,5 \\
\hline
\end{tabular}

Keterangan: (1) 1 = Kurang, 2 = Cukup, 3 = Baik, 4 = Baik sekali; (2) Dari skor diberikan penilaian 0-100

Dengan demikian, kegiatan ini sesuai dengan kebutuhan masyarakat Pesidi 1. Setelah kegiatan dilakukan, dapat memunculkan aspek pemberdayaan masyarakat dan meningkatkan motivasi masyarakat dalam bidang kewirausahaan. Hal ini didukung oleh sikap atau perilaku pengabdi di lokasi selama pengabdian dilaksanakan. Di awal kegiatan kurang dapat berkomunikasi dengan masyarakat secara langsung dikarenakan adanya pandemi yang tidak memungkinkan untuk berkerumun, oleh karena itu hanya bisa bertemu dengan pengelolanya saja. Akan tetapi, untuk kegiatan selanjutnya dibuat jadwal kegiatan dan list peserta yang terbatas yang dapat mengikuti kegiatan. Hal ini dapat dilihat dari kegiatan pengabdian yang dapat mendorong kemandirian pelaku usaha dan pengrajin serta masyarakat dapat merasakan manfaatnya. Sedangkan untuk melihat kinerja para pengrajin dapat dilihat pada tabel 5 berikut ini. 
ABDIMAS: Jurnal Pengabdian Masyarakat Universitas Merdeka Malang Volume 6, No 3, August 2021: 384-394

Tabel 5. Kinerja pengusaha

\begin{tabular}{|c|c|c|c|c|c|c|}
\hline \multirow{2}{*}{ Aspek yang diamati } & \multicolumn{5}{|c|}{ Skala Pengamatan (\%) } & \multirow[b]{2}{*}{ Total } \\
\hline & 1 & 2 & 3 & 4 & 5 & \\
\hline Ketepatan hadir dalam pelatihan & 0 & 0 & 0 & 30 & 65 & 95 \\
\hline $\begin{array}{l}\text { Kecermatan penggunaan digital marketing sebagai media } \\
\text { pemasaran usaha mereka }\end{array}$ & 0 & 0 & 20 & 35 & 40 & 95 \\
\hline Kerjasama dengan sesama peserta pelatihan & 0 & 0 & 5 & 45 & 45 & 95 \\
\hline Keterlibatan dalam diskusi & 0 & 10 & 10 & 20 & 35 & 75 \\
\hline Kemampuan mengambil keputusan atau inisiatif & 5 & 5 & 25 & 30 & 30 & 95 \\
\hline Kemampuan komunikasi dengan sesame peserta & 0 & 10 & 10 & 30 & 30 & 80 \\
\hline Ketertarikan terhadap materi pelatihan & 0 & 0 & 10 & 25 & 60 & 95 \\
\hline Kemampuan menyelesaikan tugas-tugas pelatihan & 0 & 0 & 5 & 45 & 45 & 95 \\
\hline Kualitas hasil pelatihan yang di kembangkan & 0 & 10 & 10 & 10 & 15 & 45 \\
\hline $\begin{array}{l}\text { Kemampuan menjelaskan hasil pelatihan yang dikem- } \\
\text { bangkan }\end{array}$ & 0 & 0 & 10 & 25 & 20 & 55 \\
\hline
\end{tabular}

Keterangan: (1) 1 = Sangat kurang, 2 = Kurang, 3 = Cukup, 4 = Baik, 5 = Baik sekali; (2) Dari skala pengamatan 1-5 diberikan penilaian pencapaian dalam bentuk prosentase $0-100 \%$, kemudian diakumulasi dan didapatkan hasil akhir

Untuk penilaian kinerja selama mengikuti pelatihan, pengrajin Dusun Pesidi 1 dapat menyelesaikan waktu (95\%) dalam pelatihan penggunaan digital marketing. Mereka juga sangat cermat (95\%) menggunakan teknologi handphone dalam pembuatan sosial media berupa E-mail, Facebook, Instagram, dan marketplace yang tersedia dalam platform digital. Terdapat kerjasama yang baik dengan peserta selama pelatihan berlangsung (95\%) dalam hal ini mereka saling membantu satu sama lain selama pelatihan, demikian pula peserta aktif berdiskusi dan melakukan praktik dengan cukup baik (75\%), untuk pengambilan keputusan dalam pembuatan relatif baik (95\%). Komunikasi sesama peserta pelatihan pembuatan sosial media relatif baik (80\%). Peserta memiliki ketertarikan relatif tinggi selama pelatihan (95\%) dengan penggunaan sosial media yang belum pernah mereka gunakan sebelumnya. Tugas-tugas yang harus mereka kerjakan yakni menggunakan sosial media sebagai wadah untuk menjalankan usaha mereka juga sangat baik (95\%) dan juga respon dari dunia maya yang masih kurang baik (45\%) karena sosial media masih barui ditangan mereka, sehingga penggunaan masih perlu lebih ditingkatkan. Mereka juga masih kurang (55\%) dalam menjelaskan sosial media yang mereka gunakan selama pelatihan.

\section{SIMPULAN DAN SARAN}

Program pengabdian ini dapat meningkatkan pengetahuan pengrajin dibidang digital marketing. Pelaksanaan program ini dibagi dalam 2 tahapan yaitu tahap pelaksanaan dan tahap evaluasi. Hasil yang dicapai yaitu: (1) Inovasi pemasaran melalui digital marketing dan media pemasaran menggunakan sosial media Facebook, WhatsApp, serta marketplace (sudah memanfaatkan teknologi) untuk menjual produk kerajinan yang dihasilkan; (2) Meningkatkan pemahaman pengrajin tas anyam terkait digital marketing; (3) Penjualan produk dengan sistem online; (4) Terdapat peningkatan penjualan karena adanya online shop.

Diharapkan masyarakat dapat melanjutkan program-program yang telah dilakukan serta dapat menerapkan konsep pelaksanaan kegiatan sebagaimana yang telah dilakukan. Pengrajin tas anyam Desa 
Pesidi sebaiknya menambah jumlah kerjasama dengan komunitas sosial lainnya untuk meningkatkan pemasaran produk. Pengrajin tas anyam Desa Pesidi melanjutkan pembelajaran terkait digital marketing dan ditambah dengan entrepreneurship sehingga pengrajin mendapatkan pengetahuan dari sisi akademisi dan strategi bisnis. Keterbatasan pelaksanaan kegiatan ini adalah tidak dapat memberikan solusi dari seluruh permasalahan, karena permasalahan yang dihadapi oleh mitra lebih kompleks, seperti ekspansi bisnis, pembukuan yang masih manual, loyalitas pelanggan, dan lain sebagainya. Saran kepada pengabdi berikutnya untuk dapat memberikan solusi untuk permasalahan-permasalahan tersebut.

\section{DAFTAR PUSTAKA}

Awali, H. (2020). Urgensi pemanfaatan e-marketing pada keberlangsungan UMKM di Kota Pekalongan di tengah dampak COVID-19. Balanca: Jurnal Ekonomi dan Bisnis Islam, 2(1), 1-14. https://doi.org/10.35905/balanca.v2i1.1342

Bajpai, V., Pandey, S., Shriwas, S. (2012). Social media marketing: Strategies \& its impact. International Journal of Social Science \& Interdisciplinary Research, 1(7), 214-223.

Budiyanto, H., Tutuko, P., Winansih, E., Setiawan, A. B., \& Iqbal, M. (2020). Virtual expo menggunakan panggung sebagai solusi pameran online di masa pandemi COVID-19. Abdimas: Jurnal Pengabdian Masyarakat Universitas Merdeka Malang, 5(3), 202-208.

https://doi.org/10.26905/abdimas.v5i3.4811

Chaffey, D., \& Ellis-Chadwick, F. (2019). Digital Marketing: Strategy, Implementation and Practice. 7th Edition. New York: Pearson.

Dewi, I. N. D. K., Aprilia, I., \& Supraptiningsih, L. K. (2018). Peningkatan jumlah produksi kerajinan anyaman tas dengan alat pemotong dan pengukur tali pengepak. JPPM: Jurnal Pengabdian Dan Pemberdayaan Masyarakat, 2(1), 37-42. https://doi.org/10.30595/jppm.v2i1.1791

Purwaningsih, E., Suhaeri, S., \& Ariyanti, E. R. N. (2020). Branding produk UMKM Kampung Wisata Bisnis Tegal Waru melalui reputasi merek dan basis informasi teknologi. Abdimas: Jurnal Pengabdian Masyarakat Universitas Merdeka Malang, 5(1), 60-69.

https://doi.org/10.26905/abdimas.v5i1.3392

Purwana, D., Rahmi, R., \& Aditya, S. (2017). Pemanfaatan digital marketing bagi usaha mikro, kecil, dan menengah (UMKM) di Kelurahan Malaka Sari, Duren Sawit. JPMM: Jurnal Pemberdayaan Masyarakat Madani, 1(1), 1-17. https://doi.org/10.21009/JPMM.001.1.01

Rozinah, S., \& Meiriki, A. (2020). Pemanfaatan digital marketing pada Usaha Mikro Kecil dan Menengah (UMKM) di Kota Tangerang Selatan. Jurnal Doktor Manajemen (JDM), 3(2), 134-152.

http://dx.doi.org/10.22441/jdm.v3i2.10573

Setiyaningsih, L. A., \& Fahmi, M. H. (2020). Penguatan community development petani nanas Desa Palaan melalui digital marketing. Abdimas: Jurnal Pengabdian Masyarakat Universitas Merdeka Malang, 5(2), 145-151. https://doi.org/10.26905/abdimas.v5i2.4361

Stelzner, M. A. (2015). 2015 Social Media Marketing Industry Report: How Marketers are Using Social Media to Grow Their Business. Social Media Examiner.

Supriadi, C. (2016, November 16). Di Indonesia, baru 30\% yang memanfaatkan digital untuk pengembangan bisnis. Marketing.co.id. Retrieved from:

https://marketing.co.id/dukung-wirausaha-wanita-lewat-aplikasi-dbs-businessclass/. $\quad 25$ Desember 2020. 
ABDIMAS: Jurnal Pengabdian Masyarakat Universitas Merdeka Malang Volume 6, No 3, August 2021: 384-394

Supriyani, N., \& Untari, D. (2021). Strategi dan pemanfaatan media sosial Usaha Kecil Dan Menegah (UMKM) bertahan di tengah pandemi COVID-19. Ekono Insentif, 15(1), 1-9.

https://doi.org/10.36787/jei.v15i1.419

Tinaprilia, N. (2007). Jadi Kaya dengan Berbisnis di Rumah: Kiat Praktis bagi Wanita Mencapai Kebebasan Finansial Tanpa Harus Meninggalkan Keluarga. Jakarta: Elex Media Komputindo.

We are Social. Digital in 2020. We are Social. Retrieved from: https://wearesocial.com/digital-2020 (Diakses tanggal 25 Desember 2020).

Widhiastuti, R., Kardiyem, K., \& Farliana, N. (2019). Model akuntansi sederhana bagi UMKM makanan Kota Semarang. JPPM: Jurnal Pengabdian dan Pemberdayaan Masyarakat, 3(1), 165-171. https://doi.org/10.30595/jppm.v3i1.4043 